\title{
Розвиток теорії терміна в українській та зарубіжних термінологічних школах
}

Термін — рефлекс і сила науки.

Розвиток теорії терміна тісно пов'язаний з розумінням суті наукового явища, способами відображення знань про науковий світ, принципами систематизування наукових уявлень. Термін нагромаджує й мовну інформацію, і спеціальні знання, $є$ необхідною умовою існування, зберігання, розвитку й удосконалення фахових знань.

Проведений автором цієї статті аналіз низки праць, присвячених вивченню теорії терміна, засвідчує, що теоретичні та практичні проблеми термінознавства $є$ одними з найбільш актуальних мовознавчих тем у сучасному світі. Насамперед відзначмо, що, по-перше, не в усіх роботах репрезентовані дефініції поняття „термін”, по-друге, деякі дослідники пропонують власну дефініцію, не враховуючи вже наявних пояснень. Унаслідок головний об'єкт вивчення термінознавства отримує нечітке розуміння його суті або синонімне перефразування його тлумачення.

Розвиток термінологічної діяльності як самостійного наукового напряму в Україні почався в XIX ст. у Галичині, що пов'язано з діяльністю Наукового товариства імені Шевченка (далі НТШ). Головна його мета — розвиток науки українською мовою й формування національної наукової термінології. Так, у Вступному слові першого тому Збірника НТШ (1897) Іван Верхратський та Володимир Левицький визначили програму діяльності НТШ:

Наш язик лише тогді зможе добути собі одвітного і гідного становища, коли розвинеться о стілько, щоби міг стати поруч з образованими язиками других народів Европейських, [...]. Мусить проте наш язик виробити собі одвітну термінольогію в ріжних вітах людського знання, мусить одвітно використати все богацтво рідної словнї [...]. 
Як бачимо, головне завдання НТШ - виведення української наукової мови на європейський рівень.

Найважливішим постулатом вироблення наукової термінології в європейській науці того часу вважалося спирання на національні словотвірні зразки й використання поширених у міжнародній термінології грецьких та латинських термінів і терміноелементів. Члени НТШ передусім розробляли теорію терміна, посилювали статус української мови й національної наукової термінології зокрема. Однак серед термінологів НТШ чітко сформувалися два напрями термінотворення: 1) моделювання наукових найменувань на народній основі за наявними в українській мові словотвірними (термінотвірними) зразками; 2) використання (запозичення) інтернаціональної термінології. Тогочасні українські термінологи зосереджують увагу на розробленні засад творення українських термінів і розбудові термінології. Так, у 20-30-х рр. $\mathrm{XX}$ ст. фукціювали дві українські школи: харківська (помірковані пуристи, синтетичний напрям) і київська (крайні пуристи, етнографічний напрям).

Між тим, зарубіжні термінознавці в 30-х рр. XX ст. починають активно досліджувати термін як особливу одиницю. Виникають два авторитетні центри термінологічної діяльності у світі - в Австрії (у довоєнній Німеччині) та в СРСР, що пов’язано відповідно з іменами науковців Ойгена Вюстера та Дмитра Лотте. Зокрема, засновник австрійської школи О. Вюстер 1931 р. публікує докторську дисертацію Internationale Sprachnormung in der Technik, besonders in der Elektrotechnik (Міжнародне нормування мови в техніиі, зокрема, в електротехніці), у якій закладає підвалини науки про термін. Крім того, він уперше порушує проблему нормативності й відповідності терміна потребам галузі, зокрема електротехнічної. Пізніше О. Вюстер очолює міжнародну термінологічну організацію „ІНФОТЕРМ”.

Водночас 1931 р. засновник російської школи Д. Лотте у статті Очередные задачи технической терминологии формулює не лише завдання технічної термінології, а й науково-технічної термінології загалом. До того ж він убачає необхідність класифікувати терміни, досліджувати систему аспектів терміносистеми, відстоює неприпустимість виникнення між термінами полісемії, омонімії, синонімії. 1936 р. Ернест Дрезен друкує монографію Научно-технические термины и обозначения и их стандартизация, у якій наголошує, що призначення терміна — відтворювати у свідомості людини уявлення про об'єкт науки або техніки з усіма його властивостями та якостями. 1939 р. Григорій Винокур у статті О некоторых явлениях словообразования в русской технической терминологии виділяє основні вимоги до терміна - спеціалізованість значення, точність, стилістична нейтральність. Зауважмо, що перші розробники основи теорії терміна, тобто його засновники - О. Вюстер і Д. Лотте - інженери за фахом.

Надалі в різних країнах світу створюють міжнародні національні термінологічні школи, осередки й гуртки, що продовжують розпочату роботу, зокрема: термінологічна школа Великобританії (Дженіфер Драскау, Хуан Кар- 
лос Сайгер, Фітч Томас та ін.); австрійсько-німецька термінологічна школа (Ріценгофф Глезер, Інгетраут Дальберг, Клаус Дірк Шміц та ін.); празький лінгвістичний гурток (Ян Горецькі, Ростислав Коцоурек та ін.); термінологи Польщі (Станіслав Гайда, Францишка Груча, Ванда Змарзер, Юрій Лукшин, Зигмунт Стоберскі, Пшемислав Юзвікевич та ін.).

Радянський період розвитку термінологічної думки репрезентують національні школи союзних республік СРСР: російська школа (Олександр Герд, Григорій Винокур, Сергій Гриньов, Ернест Дрезен, Володимир Лейчик, Дмитро Лотте, Олександр Реформатський, Олександра Суперанська, Олександр Хаютін, Сергій Шелов та ін.); українська школа (Тарас Кияк, Ірина Кочан, Алла Крижанівська, Таміла Панько, Людмила Симоненко, Едуард Скороходько, Фаїна Циткіна та ін.); білоруська школа (Любов Антонюк, Кіндрат Кропива, Якуб Колас, Степан Некрашевич та ін.); латвійська школа (Ілмарс Лазовскіс та ін.); литовська школа (Стасис Кейніс та ін.).

На жаль, в українському термінознавстві розвитку вчень про термін на цьому етапі перешкоджають екстралінгвальні чинники: мовна політика, деукраїнізація, ліквідування Інституту української наукової мови, переслідування й репресії українських термінологів і термінографів. На противагу цьому в Москві 1933 р. створюють при АН СРСР Комітет науково-технічної термінології, що сприяє невпинному розвитку російської наукової термінології й активному вивченню теорії терміна.

У подальші роки (30-60-і рр.) радянського періоду українська термінологія як частина наукового дискурсу лінгвістики значною мірою зазнала впливу наукових ідей двох російських мовознавців - Д. Лотте й Г. Винокура, які формулюють проблемні питання, що й нині потребують свого обговорення та розв'язання: лінгвістична сутність терміна, його природа й організація; співвідношення між термінологією та номенклатурою, стандартизування термінології тощо. Важливою подією цього періоду стала Всесоюзна термінологічна нарада 1959 р. в Москві, на якій представлені Вступне слово Віктора Виноградова й доповідь Олександра Реформатського Что такое термин и терминология?, які стали хрестоматійними.

Так, протягом 30-60-х рр. ХХ ст. виокремлюються два напрями лінгвістичного визначення терміна. Перший напрям розвивається в річищі термінологічних поглядів Д. Лотте, відповідно до яких зіставляються слово й термін, визначаються їхня природна семантична розбіжність й виокремлюються відмінні ознаки терміна — однозначність, точність, умотивованість та ін. Прихильники цього напряму головною і єдиною функцією терміна вважають номінативну, що відображає його абстрактність і символічність. Відповідно виникає поняття „,абсолютний термін”. Другий напрям продовжує традиції термінологічної школи Г. Винокура, представники якої називають терміни „особливими знаковими одиницями, що вживаються для вираження спеціальних понять” і виділяють функиійну ознаку терміна — дефінітивність 
(„Термін — це слово, яке має спеціальне, суворо окреслене значення в тій чи тій галузі знання") ${ }^{1}$.

У цей період представник лондонської термінологічної школи Теодор Сейворі пояснює терміни як „умовні знаки, призначені для передавання певного обсягу закодованої інформації, яку розуміють лише ті, хто знає відповідний ключ чи код”". Названий вище автор розглядає поняття „термін” на рівні умовних знаків і не пов'язує його з поняттями певної галузі, між якими існують логіко-поняттєві зв'язки, заперечуючи його наукову природу як поняття.

Упродовж 70-80-х pp. XX ст. в Україні розгортається теоретична термінологічна робота, хоча все ще під помітним впливом ідей російських термінологів. 3'являються праці Ірини Квітко, Тараса Кияка, Алли Крижанівської, Людмили Симоненко, Таміли Панько та ін., де здійснюється лінгвістичний опис природи терміна й особливостей розбудови термінології через призму функціоналізму (вивчення функціювання термінів, їхнє комунікативне спрямування, стилістичне розрізнення). Відповідно термін тлумачать як „невід'ємний елемент мови науки, адекватний чітко визначеному поняттю. [...] асоціюється саме 3 [...] сферою мовної комунікації, у якій він максимально збігається зі статусом репрезентанта наукового поняття"3.

Остаточне становлення українського теоретичного термінознавства як сформованої науки з предметом та методологією припадає на кінець 70-х pp.початок 80-х рр. XX ст.

У російському теоретичному термінознавстві в окреслені десятиліття відбувається перехід від структурної парадигми до структурно-функційної, що вможливлює розвиток принципово нових ідей стосовно його головних понять і категорій. Зокрема, „у межах функційного напряму термін розглядають не лише як один з лінгвістичних об'єктів, але і як засіб, за допомогою якого можна вивчати функційну природу мови, уявлення про яку пов'язане 3 вивченням вторинних, похідних понять, зокрема з формуванням і розвитком категорії терміна"4.

Наприклад, Валерій Даниленко наголошує, що „термінами називаються спеціальні поняття, які виникають не в ужитку, а у відповідних сферах наукової і практичної діяльності"5. В означеній праці автор наводить 19 де-

1 С. М. Бурдин, О терминологической лексике, „Филологические науки” 1958, № 49, c. 57.

2 T. H. Savory, The language of science, London 1967, c. 21.

3 Т. І. Панько, Від терміна до системи. Становлення марксистсько-ленінської політекономічної термінологї̈ у східнослов 'янських мовах, Львів 1979, с. 13.

4 С. Л. Мишланова, Терминоведение ХХІ века: история, напрвления, перспективы, „Филологические науки" 2003, № 2, с. 95.

5 В. В. Даниленко, Русская терминология: опыт лингвистического описания, Москва 1977, c. 14.

Slavica Wratislaviensia 172, 2020

(C) for this edition by CNS 
фініцій поняття „термін” з різних наукових джерел 40-70-х рр. XX ст. ${ }^{6}$ Цей період був плідним для розвитку термінознавства: як самостійні наукові напрями виокремлено термінографію, зіставне й галузеве термінознавство, термінологічне редагування.

Представники Празької термінологічної школи на теренах Чехії та Словаччини (Ян Горецьки, Павло Ондрус, Юрай Фурдик, Бела Поштолкова, Miрослав Рудни та ін.) у цей період також зосереджують увагу на загальних питаннях теорії терміна, зокрема на проблематиці фахової термінології як частини словникового складу мови, аналізують сучасні на той час тенденції термінотворення, вивчають склад спеціальної лексики, структуру терміна 3 огляду на особливості різних способів термінотворення, визначають вимоги до терміна, розробляють питання координації, стабілізації та нормалізації термінів, а також організації термінологічної роботи ${ }^{7}$. Учасники зазначеної школи визначають термін як одиницю професійної мови та частину професійного функційного стилю національної літературної мови ${ }^{8}$. Загалом упродовж 70-80-х pp. XX ст. теоретичні положення функційного термінознавства розробляють у Польщі; у Сербії, Хорватії, Македонії, Словенії, Україні, Білорусі, Росії з'являються дослідження антропоцентричного та лінгводидактичного спрямування; помітним стає комунікативний (у Росії, Словенії, Білорусі) та лінгвотехнологічний (у Білорусі) аспекти функційного вивчення галузевих термінологій9.

На початку 90-х pp. XX ст., після прийняття Україною незалежності, українське термінознавство відокремлюється й починає працювати у своєму руслі. Утім деякі науковці української школи продовжують дотримуватися традиційного підходу й пояснюють термін як слово чи словосполучення, що позначають поняття спеціальної галузі знань або діяльності й властиві характерні ознаки: системність (логіко-поняттєва та мовна), наявність дефініції для більшості термінів, тенденція до моносемічності в межах однієї терміносистеми, відсутність експресивності й стилістична нейтральність ${ }^{10}$.

У зарубіжному термінознавстві виникають соиіотермінознавство (socioterminology $)^{11}$, соиіокогнітивне термінознавство (sociocognitive termino-

${ }^{6}$ Ibidem, c. $83-86$.

7 І. А. Казимирова, Л. В. Туровська, Тенденції чеської (празької) термінологічної иколи на теренах Чехії та Словаччини, „Термінологічний вісник” 2013, вип. 9, с. 29.

8 H. Felber, Terminology Manual, Paris 1984, c. 35.

9 В. Л. Іващенко, Н. О. Яценко, Галузеве слов'янське термінознавство функиіональної дослідницької парадигми кіния XX-початку XXI століть, „Термінологічний вісник” 2013, вип. 9 , с. 9.

10 Т. С. Пристайко, Номинация в сфере специяльной коммуникации, Диссертация на соискание ученой степени доктора филологических наук, Днепропетровск 1996, с. 54-55.

11 J. C. Boulanger, Une Lecture socioculturelle de la terminologie, „Cahiers de Linguistique Sociale” 1991, № 18, c. 13-30; F. Gaudin, Terminologie et travail scientifique: mouvement des signes, mouvement des connaissances, „Cahiers de Linguistique Sociale” 1991, № 18, c. 111-132. 
$\log y)^{12}$. Так, у кінці XX ст. бельгійська дослідниця Рита Теммерман започатковує соціокогнітивний напрям вивчення терміна, що є альтернативним основним принципам логічного позитивізму, структуралізму, термінологічній школі О. Вюстера, Празькій, Радянській, Канадській термінологічним школам, що представляють так зване „традиційне термінознавство” (термін Р. Теммерман $)^{13}$. Цей науковець аргументовано викладає свої міркування: „Стандартизація — це боротьба за всесвітню спільність” ${ }^{4}$; „, [...] важливо, що основною мотивацією для кожної школи термінознавства, здається, є мовне планування. Для Празької, Радянської і Віденської шкіл характерне тяжіння до стандартизації” 15 ; „Нова соціокогнітивна теорія термінознавства вимагає, щоб термінологія не була однозначно зорієнтована на стандартизацію й ставить під сумнів необхідність об'єктивізму як теоретичної основи термінознавства"16.

Отже, Р. Теммерман розрізняє дві теорії: 1) теорію „традиційного термінознавства", відповідно до якої основною операційною одиницею термінознавства є поняття, що існує об'єктивно; терміни називають поняття, які вибудовуються в логічно та онтологічно структуровану систему понять; дефініція поняття відображає позицію поняття в логічній та онтологічній поняттєвій системі, наприклад, суттєві сторони поняття визначаються за родо-видовими ознаками, зв'язками із суміжними поняттями; 2) теорію „соціокогнітивного термінознавства”, відповідно до якої основна одиниця термінознавства - одиниия розуміння спеиіального знання; терміни — це двигуни процесу розуміння, осягнення світу, оскільки вони поєднують нові етапи розуміння 3 попередніми етапами; одиниці розуміння функціюють в ідеалізованих когнітивних моделях - пропозиційних та метафоричних („Метафора є частиною розуміння термінів у дискурсі”17); терміни можуть характеризуватися багатозначністю, омонімією, синонімією, метафоричним перенесенням, вони можуть змінювати своє значення в діахронії ${ }^{18}$. Вивчивши положення теорії терміна Р. Теммерман, Тетяна Стасюк зауважує, що „новий напрям викликав до життя цілу низку понять і поглядів, які зумовили утворення ланцюжків змін у всій теорії західного термінознавства"19.

На початку XXI ст. представниця іспанської школи Марія Тереза Кабре Кастельві розробляє комунікативну теорію термінознавства (the com-

12 R. Temmerman, Questioning the Univocity Ideal. The difference between scio-cognitive Terminology and Traditional terminology, „Hermes: Journal of Linguistics” 1997, № 18, c. 51-90.

13 Ibidem, c. 53.

14 Ibidem, c. 54.

15 Ibidem, c. 53.

16 Ibidem, c. 54

17 Ibidem, c. 83 .

18 Ibidem, c. 53-54.

19 Т. В. Стасюк, Короткий огляд положень теорї терміна Рити Теммерман, „Науковий вісник кафедри ЮНЕСКО”, серія „Філологія. Педагогіка. Психологія” 2013, вип. 26, с. 110. 
municative theory of terminology) ${ }^{20}$. На переконання вченої, термінознавство повинно виробити єдину методологічну структуру для дослідження терміносистем різних галузей знань. Науковець уважає, що одиниці мови для спеціальних цілей є багатовимірними, у них, як і в загальновживаних словах, закладені й когнітивний, і лінгвістичний, і соціокомунікативний компоненти, специфіку ж зумовлюють когнітивні, синтаксичні та прагматичні особливості, що визначають їхню належність до певної галузі знань. М. Т. Кабре Кастельві розглядає терміни як set sof conditions (набір умов), щоб їх розуміти й аналізувати, вона розробляє „теорію дверей” і пропонує уявити концепт багатогранником - просторовою фігурою. У спрощеному вигляді концепт має три виміри - когнітивний, лінгвістичний і комунікативний. Кожен із цих вимірів - двері, під час вибору одного не можна не враховувати інших ${ }^{21}$.

Одним $з$ останніх напрямів термінознавства, що розробляється в сучасному мовознавстві, як видається, є фреймове термінознавство, що його досліджує іспанська дослідниця Памела Фабер Бенітес. За її визначенням,

фреймове термінознавство [...] — ще один дуже пізній когнітивний підхід термінознавства, який спирається на багато спільних передумов і КТТ [комунікативну теорію термінознавства], і соціокогнітивне термінознавство. Наприклад, воно намагається знайти відмінність між термінами й словами, [...], а це найкращий спосіб для вивчення спеціалізованих одиниць знань, дослідження їхньої поведінки в текстах. Тому що загальною функцією спеціалізованих мовних текстів є передавання знань, такі тексти, як правило, відповідають шаблонам для полегшення розумінняя 22.

Українське термінознавство початку XXI ст. хоча й розвивається головно в річищі традиційних поглядів стосовно терміна та наукових напрямів і аспектів (зокрема загальному, галузевому, типологійному, порівняльному, семасіологічному ономасіологічному, історичному, функційному), однак, як наголошує Вікторія Іващенко,

формується новий підрозділ — когнітивне (когнітивно-дискурсивне) термінознавство, або, як його ще називають, когнітивно-комунікативне, чи гносеологічне, термінознавство, що, з одного боку, продовжує усталені традиції в царині теорії терміна, а з другого - набуває рис, притаманних сучасному етапові наукового пізнання, — міждисциплінарність (експансіонізм), відкритість, асистемність, поліпарадигмальність, антропоцентризм, синергетизм ${ }^{23}$.

${ }^{20}$ M. T. Cabré Castellví, Theories of Terminology. Their Description, Prescription and Explanation, „Terminology. International Journal of Theoretical and Applied Issues in Specialized Communication" 2003, т. 9, № 2, http://www.jbe-platform.com/content/journals/10.1075/term.9.2.03cab [доступ: 23.09.2018].

21 Ibidem.

22 B. P. Faber, The Cognitive Shift in Terminology and Specialized Translation, [в:] MonTI. Monografías de Traducción e Interpretación, red. M. del Carmen, J. F. Aixelá, Valencia 2009, № 1, c. 120 .

23 В. Іващенко, Когнітивне термінознавство: перспективи розвитку, „Термінологічний вісник” 2013, вип. 1, с. 48.

Slavica Wratislaviensia 172, 2020

(C) for this edition by CNS 
Крім того, зазначений термінознавець зауважує:

На сьогодні наука працює на теоретичній (теоретичній та методичній) основі сучасної мульти-парадигми як внутрішній і міждисциплінарний синтез конкретної галузі знань, логіки, системології, семіотики та мовознавства шляхом їхньої екстраполяції в український досвід. Це вимагає адаптації методології системного мовознавства, загальної теорії методів термінологічного дослідження в Україні шляхом розробки відповідної методики на основі теоретичної та практичної методології ${ }^{24}$.

За спостереженням автора цього дослідження, сучасне термінознавство розвивається, спираючись на багатолітні напрацювання, історію традиційного напряму та новітні нетрадиційні погляди.

Сучасні українські мовознавці досліджують термін як особливий мовний знак серед лексем національної мови, звертають увагу на специфіку його семантики, особливості вияву парадигматичних відношень, генезу, будову й структуру, дублетність і варіантність, що потребують унормування, уніфікування й кодифікування. Утім найважливішою проблемою сучасного українського термінознавства $є$ збереження національного характеру української термінології за умов широких глобалізаційних процесів сучасності.

Отже, світове термінознавство початку нового століття характеризується багатовекторними підходами до розуміння його основних теоретичних принципів. Зокрема, його пошукова парадигма репрезентована кількома напрямами: традиційним (функційним) та новітніми — когнітивним, соціокогнітивним, комунікативним, фреймовим.

Термінознавство як наука має тривалу історію, але зміст його базової поняттєвої одиниці „термін” безперервно доповнюється, уточнюється, переосмислюється. Сруктурно-семантичний аналіз пояснень поняття „термін” у діахронії засвідчує, що жодна із запропонованих представниками світових термінологічних шкіл дефініцій не $є$ загальноприйнятою та універсальною, тобто від витоків до сьогодні не існує єдиного визначення головного поняття термінознавства, однак відстежуємо загальну думку, що лежить в основі його пояснень. Дослідники допускають, що терміном може бути й слово, i словосполучення, i знак, i акронім, i абревіатура, i символ, і поєднання слова й букв-символів, а також поєднання слова та цифр-символів. Ключовим у визначенні терміна є дотримання „триєдиної основи терміна — предметне знання, логічне осмислення і мовне вираження" 25 , а також його зв'язок зі спеціальним поняттям та системою понять.

24 W. Iwaszczenko, Ukrainian School of Terminology, [в:] Polskie i europejskie nurty terminologiczne, ред. М. Małachowicz, S. Grucza, Warszawa 2017, с. 224, portal.uw.edu.pl/documents /7732735/0/SN+38+M.+Małachowicz\%2C\%20S.Grucza\%2C\%20Polskie+i+europejskie+nurty+terminologiczne.pdf [доступ: 22.01.2019].

25 А. В. Суперанская, Н. В. Подольская, Н. В. Васильева, Общая терминология: Вопросы теории, Москва 1989, с. 17. 
Сучасна термінознавча наука вийшла на новий рівень свого розвитку. Вона продовжила напрацьовані традиції, але більшою мірою зазнала змін, переосмислила й виробила нові погляди. За спостереженнями зарубіжних науковців Герберта Пічта й Кристера Лорена, основні термінознавчі концепції провідних шкіл світу (Віденської, Радянської, Празької, Канадської, Німецької та Скандинавської) збігаються стосовно розуміння основних понять теорії терміна. Істотно відрізняються тим, що вони написані різними мовами й застосовані до різних галузей науки ${ }^{26}$. На сьогодні найбільш активними та прогресивними є бельгійська, французька, іспанська й російська термінологічні школи.

Теоретичні ідеї зарубіжних термінологічних шкіл є піонерними та панівними в Україні. Формування теорії терміна в українському термінознавстві зумовлене екстралінгвальними чинниками, запитами національного життя й науки, досягненням світової наукової думки. Сучасний стан розвитку української теорії терміна характеризується посиленням уваги до когнітивних аспектів вивчення термінології. Перспективу дослідження вбачаємо у вивченні ознак та функцій сучасного терміна в діахронії.

\section{Бібліографія}

Boulanger J. C., Une Lecture socioculturelle de la terminologie, „Cahiers de Linguistique Sociale” 1991, № 18.

Burdin S. M., O terminologičeskoj leksike, „Filologicheskiye nauki” 1958, № 4.

Cabré Castellví M. T., Theories of Terminology. Their Description, Prescription and Explanation, „Terminology. International Journal of Theoretical and Applied Issues in Specialized Communication” 2003, t. 9, № 2, http://www.jbe-platform.com/content/journals/10.1075/ term.9.2.03 cab.

Danilenko V. V., Russkâ̂ terminologiâ. opyt lingvističeskogo opisaniâ, Nauka, Moskva 1977.

Faber B. P., The Cognitive Shift in Terminology and Specialized Translation, [v:] MonTI. Monografias de Traducción e Interpretación, red. M. del Carmen, J. F. Aixelá, Valencia 2009, № 1.

Felber H., Terminology Manual, UNESCO, Paris 1984.

Gaudin F., Terminologie et travail scientifique: mouvement des signes, mouvement des connaissances, „Cahiers de linguistique sociale” 1991, № 18.

Iwaszczenko W., Ukrainian School of Terminology, [v:] Polskie i europejskie nurty terminologiczne, red. M. Małachowicz, S. Grucza, Warszawa 2017, portal.uw.edu.pl/documents/7732735/0/ $\mathrm{SN}+38+\mathrm{M} .+$ Małachowicz $\% 2 \mathrm{C} \% 20 \mathrm{~S}$.Grucza $\% 2 \mathrm{C} \% 20$ Polskie+i+europejskie+nurty+terminologiczne.pdf.

İvaŝenko V. L., Âcenko N. O., Galuzeve slov 'âns'ke termìnoznavstvofunkcìnal'nö̈ doslidnic'kö̈ paradigmi kìncâ XX-počatku XXI stolit', „Termìnologičnij vìsnik” 2013, vip. 9.

İvaŝenko V., Kognitivne terminoznavstvo:perspektivi rozvitku, „Termìnologičnij vìsnik” 2013, vip. 1.

Kazimirova I. A., Turovs'ka L. V., Tendenciïčes'kö̈ (praz'koï) terminologičnoï školi na terenah Čehï ta Slovaččini, „Termìnologičnij vìsnik” 2013, vip. 9.

${ }^{26}$ H. Picht, Modern Approaches to Terminological Theories and Applications, [в:] Contributions 15th European Symposium on Languages for Special Purposes, pед. H. Picht, Bern-BerlinFrankfurt am Main-New York-Wien 2006, c. 441.

Slavica Wratislaviensia 172, 2020

(C) for this edition by CNS 
Mišlanova S. L., Terminovedenie XXI veka: istoriâ, naprvleniâ, perspektivy, „Filologičeskie nauki” 2003, № 2.

Pan'ko T. İ., Vid termina do sistemi. Stanovlennâ marksists'ko-lenìns'koï politekonomičnoï terminologiï u shìdnoslov 'âns'kih movah, Viŝa škola, L'vìv 1979.

Picht H., Modern Approaches to Terminological Theories and Applications, [v:] Contributions 15th European Symposium on Languages for Special Purposes, red. H. Picht, Bern-Berlin-Frankfurt am Main-New York-Wien 2006.

Pristajko T. S., Nominaciâ v sfere special'noj kommunikacii, Dissertatsiya na soiskaniye uchenoy stepeni doktora filologicheskikh nauk, Dnepropetrovsk 1996.

Savory T. H., The language of science, Published by Andre Deutsch, London 1967.

Stasûk T. V., Korotkij oglâd položen' teorï termina Riti Temmerman, [v:] Naukovij vìsnik Kafedri ÛNESKO, Seriâ „Fìlologiâ. Pedagogika. Psihologiâ” 2013, vip. 26.

Superanskaâ A. V., Podol'skaâ N. V., Vasil'eva N. V., Obŝaâ terminologiâ: Voprosy teorii, Nauka, Moskva 1989.

Temmerman R., Questioning the Univocity Ideal. The difference between scio-cognitive Terminology and Traditional terminology, „Hermes: Journal of Linguistics” 1997, № 18.

\section{Development of the theory of a term in Ukrainian and foreign terminological schools}

Summary

The purpose of the article is monitoring the development of the theory of a term, in particular, the evolution of linguistic approaches to determine the essence of a term by various world terminological schools in diachrony (from the 1930s to the 2010s). The subject of the study is a presentation of the theory of a term developed by representatives of both Ukrainian and foreign terminology schools. Belgian, French, Spanish, and Russian terminology schools are considered to be the most active, progressive, and influential in the world. While studying the theory of a term the traditional (functional) and the innovative (cognitive, socio-cognitive, communicative, framed) directions are mostly used. The theoretical ideas of foreign terminology schools are pioneering and dominant in Ukraine. The current state of development of the Ukrainian (as well as foreign) theory of a term is characterized by increased attention to the cognitive aspects of the terminology study.

Keywords: term, terminology, terminology school, theory of a term, directions of studying the theory of a term

\section{Развитие теории термина в украинской и зарубежных терминологических школах}

Резюме

Цель статьи - отследить особенности развития теории термина, в частности эволюцию лингвистических подходов к определению сущности термина разными терминологическими школами мира в диахронии (от 30-х гг. XX в. до 10-х гг. XXI в.). Предмет

Slavica Wratislaviensia 172, 2020

(C) for this edition by CNS 
исследования - описание теории термина с учетом основополагающих разработок представителей украинской и зарубежных терминологических школ. Наиболее активными, прогрессивными и влиятельными считаются бельгийская, французская, испанская и русская терминологические школы. При изучении теории термина чаще всего актуализируются традиционное (функциональное) и новейшие (когнитивное, социокогнитивное, коммуникативное, фреймовое) направления. Теоретические идеи зарубежных терминологических школ являются пионерскими и господствующими на Украине. Современное состояние развития украинской (как и зарубежной) теории термина характеризуется усилением внимания к когнитивным аспектам изучения терминологии.

Ключевые слова: термин, терминоведение, терминологическая школа, теория термина, направления изучения теории термина 